\title{
REACTIVATION OF TUBERCULOSIS AND COVID-19
}

\author{
Gokcen Unal ${ }^{1}$, Fadime Ceyda Eldeniz ${ }^{2}$, Asli Yilmaz ${ }^{2}$, Ozge Metin Akcan ${ }^{2}$, Necdet Poyraz $^{2}$, \\ Fahriye Kılınç ${ }^{1}$, Sevgi Keleş ${ }^{2}$, Ayşe Bulut ${ }^{3}$, and Sevgi Pekcan ${ }^{2}$ \\ ${ }^{1}$ Necmettin Erbakan Universitesi Meram Tip Fakultesi Hastanesi \\ ${ }^{2}$ Necmettin Erbakan University Meram Medical Faculty Hospital \\ ${ }^{3}$ TC. sağlık bakanlığı verem savaş dispanseri, konya
}

November 27, 2021

\begin{abstract}
Coronavirus disease 2019 (COVID-19) is a viral disease caused by a novel coronavirus that can lead to severe acute respiratory failure. Recent studies have shown that aggravating factors in the etiology of COVID-19 disease include genetic defects and autoantibodies against type 1 interferon. Mycobacterium tuberculosis is an immobile aerobic bacillus that causes tuberculosis disease. SARS-CoV-2 infection and immunosuppressive drugs may temporarily inhibit immunologic system, then may lead to active tuberculosis by reactivation or infection of $\mathrm{M}$. tuberculosis. We aimed to show that there is a relationship between covid19 infection and an increase in the number of tuberculosis patients. Eight patients diagnosed with tuberculosis in the Pediatric Pulmonology and Pediatric Infectious Diseases Clinics of Necmettin Erbakan University, Meram Medical Faculty between March 2020 and May 2021 were enrolled in this study. The presence of COVID-19 infection was confirmed by COVID-19 antibody test and patient's detailed medical history. The patient with negative antibody test was also included in the study if other family members confirmed for COVID-19 infection by RT-PCR. We evaluated demographic data, laboratory findings, imaging tests and pathology results of all patients. The remarkable increase in the number of tuberculosis activation in the recent year suggests the role of COVID-19 infection. The pathologic structure of the virus may be responsible of the increase, although the mechanism is not fully understood. Further research should be done on this topic.
\end{abstract}

\section{INTRODUCTION}

Coronavirus disease 2019 (COVID-19) is a viral disease caused by a novel coronavirus that can lead to severe acute respiratory failure. It was first identified in December 2019. In a short time, it became a global and emergent health problem [1].

Coronaviruses belong to a family of enveloped, single-stranded, zoonotic RNA viruses that can be transmitted from animals to humans, mutate rapidly and recombine. Severe Acute Respiratory Syndrome Coronavirus-2 (SARS-CoV-2) is transmitted by inhalation of respiratory droplets from an infected person or by touching virus-contaminated surfaces. In previous epidemics, pediatric cases accounted for $6.9 \%$ of total SARS-2002-3 cases and $2 \%$ of Middle East Respiratory Syndrome (MERS) cases. Data from the Centers for Disease and Prevention (CDC) show that children accounted for $12.3 \%$ of all SARS-CoV-2 cases; $2.1 \%$ were $0-4$ years old, and $10.2 \%$ were $5-17$ years old [2].

COVID-19 infection may progress with a cytokine storm following viral proliferation phase that may lead to acute respiratory distress syndrome (ARSD), impaired cardiac function and death. Cytokine storm is due to the dysregulated immune response of the host [3,4]. In this infection, older age, male sex, chronic obstructive pulmonary disease, hypercholesterolemia and diabetes are among the independent risk factors associated with mortality. Recent studies have shown that aggravating factors in the etiology of COVID-19 disease include genetic defects and autoantibodies against type 1 interferon $[5,6]$. 
Mycobacterium tuberculosis is an immobile aerobic bacillus that causes tuberculosis disease (TB). It is transmitted by infected droplets. Whether infection develops after transmission depends on the frequency and duration of the contact, distance to the contact, the amount and virulence of the transmitted pathogen, and the susceptibility of the exposed person. After inhalation of the bacillus, it usually settles in the better ventilated upper regions of the lungs. In healthy individuals, T-cells inhibit intracellular proliferation of the bacillus 3-4 weeks after the infection. In this way, the disease is brought under control. Clinically significant TB may develop shortly after the disease, particularly in children and immunosuppressed individuals [7].

Tuberculosis remains a major cause of mortality and morbidity in developing countries. More than 95\% of tuberculosis-related deaths occur in low- and middle-income countries. About one-third of the world's population has latent tuberculosis infection $[8,9]$.

SARS-CoV-2 infection and immunosuppressive drugs may temporarily inhibit immunologic system, then may lead to active tuberculosis by reactivation or infection of M. tuberculosis [10]. Although studies showed an increase in the frequency of tuberculosis in previous SARS, MERS and H1N1 epidemics, no such information has yet been found for COVID-19 infections [11-15]. In this study, we aimed to investigate the association between COVID-19 infection and increase in tuberculosis cases during the pandemic.

\section{MATERIALS AND METHODS}

Eight patients diagnosed with tuberculosis in the Pediatric Pulmonology and Pediatric Infectious Diseases Clinics of Necmettin Erbakan University, Meram Medical Faculty between March 2020 and May 2021 were enrolled in this study. We obtained approval from the Ethics Committee of Necmettin Erbakan University with decision number 2012/3106. The presence of COVID-19 infection was confirmed by COVID-19 antibody test and patient's detailed medical history. The patient with negative antibody test was also included in the study if other family members confirmed for COVID-19 infection by RT-PCR. We evaluated demographic data, laboratory findings, imaging tests and pathology results of all patients.

\section{RESULTS}

Seven of the eight patients were female $(87.5 \%)$, and one was male (12.5\%). The median age was 16 (years) (min: 13.5, max: 17). Only one of the patients was a migrant from Syria (12.5\%) and remaining ones were Turkish.

Fever $(75 \%)$, cough $(75 \%)$, side pain $(37.5 \%)$, and swelling at neck (12.5\%) were most common complaint of the patients at admission. Four patients had a history of COVID-19 infections. COVID-19 antibody test was positive at six patients. COVID-19 antibody was negative in only a patient and the patient had not been tested for COVID-19 because he had no complaints when his parents with whom they lived in the same house, were COVID-19 positive. The families reported that none of them had any complaint and received any therapy for covid-19 infection. There was no record about their admission to hospital in our national medical database. Patients were diagnosed as $\mathrm{Tb}$ at the based on clinical findings, imaging studies, PPD test, pathologic examination of biopsy samples and quantiferon test (Table 1 and Figure 1).

Family screening of all patients was negative, and they had BCG scars. One of the patients had culture positivity (patient 7) and was not resistant to first-line drugs. Only a patient had tuberculosis lenfadenitis as extrapulmonary tuberculosis (patient 6). None of our patients had CD 4 lymphopenia and their HIV tests were also negative.

Two of the patients had chronic disease. One of them diagnosed as primary ciliary dyskinesia in our departmant (patient 8) and second one was following by rheumatology departmant for the diagnosis of juvenile idiopathic rheumatoid arthritis (JIA). P1, admitted to the pediatric infectious disease in patient clinic due to a pleural effusion while receiving TNF-alpha inhibitor for juvenile idiopathic rheumatoid arthritis (JIA). Since TNF-alpha inhibitor treatment was considered responsible for the activation of tuberculosis, we stopped the therapy. The patient had a history of COVID-19 disease which confirmed by PCR. In spite of appropriate antibiotic treatment and discontinuation of TNF alpha inhibitor, the effusion did not regress. Pleural biopsy revealed a necrotizing granulomatous infection (Figure 2). Thus, anti-tuberculosis therapy 
including isoniazid, rifampicin, pyrazinamide, ethambutol were started. Because of JIA, Tb and extended hospitalization in the patient, immunologic evaluation was performed. His immunological evaluation revealed hypogammaglobulinemia and low memory B cell. Since the patient met the diagnostic criteria for primary immunodeficiency according to ESID, we started IVIG treatment. Almost 6 months after the first COVID19 positive PCR test, the patient admitted to hospital with complaint of fever and cough for the second time and was found to be COVID-19 positive. Then, he hospitalized and treated. Whole exome sequencing which was done for suspicion of common variable immunodeficiency showed an autosomal dominant heterozygous mutation in TNFRSF13B gene (c.204insT ). None of the other patients had an underlying chronic disease.

Immunologic evaluation was done to all 8 patients at the time of diagnosis due to their severe clinical presentation then expected for this age group (Table 2). The results are summarized in Table 2. During the infection, only a patient (patient \# 2) had lymphopenia but turn to normal count at the first month of anti $\mathrm{Tb}$ treatment. One patient had low serum IgG levels (patient \# 1). Two patients had borderline low serum IgG1 levels and one patient had borderline low serum IgM levels [16]. When the peripheral lymphocyte subset was examined, B cells were low in only a patient (patient\#2), B cell count could not re-evaluated because the patient did not come to our clinic for follow-up. Natural killer (NK) cells were low in five patients. We could check three of our patients with low NK levels, it returned to normal in patients other than p1 (Table 2).

\section{DISCUSSION}

Tuberculosis is most common infectious disease in developing countries. Immune system dysfunction, treatment with immunosuppressive drugs, chronic diseases such as diabetes, and chronic renal failure are known to increase susceptibility to tuberculosis. These risk factors are not mutually exclusive, and their coexistence can worsen in the course of the disease. However, because the immune dysfunction they cause varies, the correlation between comorbidities and disease susceptibility is complicated [17].

Coronaviruses have been known to cause occasional pandemics. The studies in the literature that examined correlations between SARS, MERS, H1N1, and reactivation of tuberculosis during these periods showed that cellular immunity associated with this infection was temporarily suppressed and reactivation of latent tuberculosis or a new TB infection occurred [11-15]. There is no such information on SARS-Cov-2 yet. We have done a retrospective study in our clinic and found that the number of patients diagnosed with TB has increased. Examination of the number of children diagnosed with TB in the pediatric pulmonology and pediatric infectious disease clinics at our hospital by year between 2017 and 2021 shows that three pediatric patients were diagnosed with tuberculosis and received treatment in 2017, four in 2018, eight in 2019, and 23 in 2020- April 2021. When we scanned the number of pediatric patients diagnosed with tuberculosis in Konya by years, we found that 21 children were diagnosed with tuberculosis in 2017, 21 children in 2018, 27 children in 2019, 33 children in 2020, and 13 children until April 2021. Despite the decrease in the child population in Konya, there was a remarkable increase in the number of pediatric tuberculosis cases (Table 3) $[18,19]$.

We checked all our patients with TB by Covid-19 antibody $(\operatorname{IgG}+\operatorname{IgM})$ or PCR. Only eigth of the patients was positive. Of the eight patients with positive PCR or antibody, two (\%25) had cavitary lesions, three $(\% 37,5)$ had pleural effusion, and one $(\% 12,5)$ had pleural and pericardial effusion. Remaining 15 patients with negative PCR or antibody have mild fenotipe including two $(\% 13,3)$ had pleural effusion and three (\%20) had cavitary lesion.

We could not test the presence of autoantibodies against interferon type 1 in any of them. Both innate and acquired immunity play important roles in the immune response against Mycobacterium tuberculosis. T lymphocytes, dendritic cells, Toll-like receptors, IFN-gamma, TNF-alpha, and IL-12 play important role immune response to Mycobacteria [20]. There is an increased susceptibility to tuberculosis in primary immunodeficiencies with defects in these cells and pathways.

The primary immunodeficiencies known to predispose to tuberculosis are T-cell deficiencies, chronic granulomatous disease and Mendelian susceptibility to mycobacterial diseases. The unexpectedly severe clinical 
findings of tuberculosis in our patients suggested primary immunodeficiency, while the immunological evaluation revealed a CVID diagnosis in one patient (patient \#1) and mild immunological defects in the other patients that did not meet ESID criteria for a primary immunodeficiency. Lymphopenia was present in only one of our patients, and improvement at the follow-up suggested a temporary situation secondary to the infection.

Physical activity can affect NK cells; their number can change even throughout the day. We do not yet know the importance of the low NK cell count detected in four of our patients during the disease. but turn to normal levels at follow up (except in the \# 1 patient). Consequently, the activation of TB seems to be due to the structure of the COVID-19 virus and its pathological characteristics.

There are few studies on COVID-19 and tuberculosis. Jain et al. showed that the risk of SARS-CoV-2 infection is increased in patients with latent tuberculosis and there is a susceptibility to severe COVID-19 pneumonia. Additionally, it is indicated that the COVID-19 pandemic leads to a decrease in admission to health facilities and to a delay in diagnosing tuberculosis [21]. Can Sarinoğlu et al.' simultaneously requested COVID-19 and tuberculosis tests in 30 patients since March 2020 and found that 26.6\% of 30 patients was immunosuppressed (malignancy, hematopoietic stem cell transplantation, positive HIV test). Two out of 30 patients had both COVID-19 PCR and tuberculosis test positive. One of these two patients had diabetes, hypertension, chronic obstructive lung disease, and chronic renal failure. The other patient had no underlying disease [22]. Our study also supports that a COVID-19 infection changes the individual's immune system and causes tuberculosis infection.

In previous studies and case reports, it has been shown that covid-19 causes TB reactivation and newly diagnosed TB, but all the patients in this study were adult except one patient diagnosed with congenital TB. There have been no studies on children since the beginning of the pandemic period. Our patients had comorbidities such as immunodeficiency, however, none of our patients died [23-27].

The remarkable increase in the number of tuberculosis activation in the recent year suggests the role of COVID-19 infection. The clinical findings of the respiratory diseases that are secondary to infections progress similar to TB. Therefore, the diagnosis of TB may easily be missed. Since TB is a slowly progressing infection, there may be delays in diagnosis. It has been observed that latent TB infection can be activated even if the covid-19 infection is mild in children. Covid-19 infection is not as innocent as it seems for children either.

The experiences of our clinic and our country support the impression that the increase in recent year is due to increased TB cases associated with the pandemic. This should be kept in mind in case of cavity lesions and pleurisy. Moreover, the presence of a possible underlying immunodeficiency should be investigated in the case of complicated respiratory infections. The pathologic structure of the virus may be responsible of the increase, although the mechanism is not fully understood. Further research should be done on this topic.

Table 1. Demographic and clinical results

\begin{tabular}{|c|c|c|c|c|c|c|c|c|}
\hline Patient no & Age (year) & Sex & PPD & Quantiferon & Tomography & Pathology & Diagnosis & Medica \\
\hline $\mathrm{p} 1$ & 16 & Male & Negative & Positive & $\begin{array}{l}\text { Paratrecheal } \\
\text { lym- } \\
\text { phadenopa- } \\
\text { thy, pleural } \\
\text { effusion, } \\
\text { Pneumonic } \\
\text { consolidation }\end{array}$ & $\begin{array}{l}\text { Necrotizing } \\
\text { Granulam- } \\
\text { atous } \\
\text { inflammation }\end{array}$ & Pathology & $\mathrm{H}, \mathrm{R}, \mathrm{Z}, \mathrm{H}$ \\
\hline p2 & 16 & Female & $30 \mathrm{~mm}$ & Positive & $\begin{array}{l}\text { Pleural } \\
\text { effusion, } \\
\text { atelectasis }\end{array}$ & - & Clinically & $\mathrm{H}, \mathrm{R}, \mathrm{Z}, \mathrm{H}$ \\
\hline
\end{tabular}




\begin{tabular}{|c|c|c|c|c|c|c|c|c|}
\hline Patient no & Age (year) & Sex & PPD & Quantiferon & Tomography & Pathology & Diagnosis & Medica \\
\hline p3 & 17 & Female & Negative & Positive & $\begin{array}{l}\text { Pleural } \\
\text { effusion }\end{array}$ & $\begin{array}{l}\text { lymphocyte- } \\
\text { rich } \\
\text { fluid }\end{array}$ & Clinically & $\mathrm{H}, \mathrm{R}, \mathrm{Z}$ \\
\hline $\mathrm{p} 4$ & 13,5 & Female & $1 \mathrm{~mm}$ & Negative & $\begin{array}{l}\text { Pleural, } \\
\text { pericar- } \\
\text { dial } \\
\text { effusion }\end{array}$ & $\begin{array}{l}\text { active } \\
\text { chronic } \\
\text { inflammation }\end{array}$ & Pathology & $\mathrm{H}, \mathrm{R}, \mathrm{Z}, \mathrm{I}$ \\
\hline $\mathrm{p} 5$ & 16 & Female & $6 \mathrm{~mm}$ & İnderteminate & $\begin{array}{l}\text { Cavity, } \\
\text { medi- } \\
\text { astinal } \\
\text { lym- } \\
\text { phadenopa- } \\
\text { thy,Pneumoni } \\
\text { consolidation }\end{array}$ & $\begin{array}{l}- \\
\text { c }\end{array}$ & Clinically & $\mathrm{H}, \mathrm{R}, \mathrm{Z}$ \\
\hline $\mathrm{p} 6$ & 13,5 & Female & $17 \mathrm{~mm}$ & Positive & $\begin{array}{l}\text { Thorax } \\
\text { CT: } \\
\text { Normal } \\
\text { Neck CT: } \\
\text { central } \\
\text { necrotic } \\
\text { conglomer- } \\
\text { ate } \\
\text { lymphadenopa }\end{array}$ & $\begin{array}{l}\text { necrotizing } \\
\text { granuloma- } \\
\text { tous } \\
\text { lymphadenitis } \\
\text { thy }\end{array}$ & $\begin{array}{l}\text { Pathology } \\
\text { TB } \\
\text { DNA }(+)\end{array}$ & $\mathrm{H}, \mathrm{R}, \mathrm{Z}$ \\
\hline $\mathrm{p} 7$ & 16 & Female & $7 \mathrm{~mm}$ & - & $\begin{array}{l}\text { Cavity, } \\
\text { budding } \\
\text { tree ap- } \\
\text { pearance, } \\
\text { Mediastinal } \\
\text { calcified } \\
\text { and } \\
\text { noncalcified } \\
\text { lap }\end{array}$ & - & $\begin{array}{l}\operatorname{ARB}(+) \\
\text { Culture }(+)\end{array}$ & $\mathrm{H}, \mathrm{R}$, \\
\hline 8 & $\begin{array}{l}13 \text { year } \\
8 \text { month }\end{array}$ & Female & Negative & - & $\begin{array}{l}\text { Situs } \\
\text { inversus } \\
\text { totalis }\end{array}$ & - & $\begin{array}{l}\text { TB } \\
\mathrm{DNA}(+)\end{array}$ & $\mathrm{H}, \mathrm{R}, \mathrm{Z}, \mathrm{I}$ \\
\hline
\end{tabular}

H: Isoniazid, R: Rifampicin, Z: Pyrazinamide, E: Ethambutol

Table 2. Laboratory results

\begin{tabular}{lllllllll}
\hline $8 / 13,7$ & $7 / 13$ & $6 /$ & $5 / 16$ & $4 /$ & $3 /$ & $2 /$ & $1 /$ & Patient N \\
& & 13,5 & & 13,5 & 17 & 16 & 16 & Age(year) \\
\hline 7870 & 13400 & 10470 & 14900 & 16670 & 8270 & 6640 & 14620 & WBC \\
4710 & 10890 & 6290 & 10690 & 12340 & 5420 & 4870 & 10450 & ANS \\
2480 & 1560 & 3480 & 2160 & 2730 & 1770 & 1130 & 3120 & ALS \\
5 & 41 & 15 & 98 & 73 & 84 & 93 & 26 & Sed. \\
0,2 & 78 & 1 & 145 & 308 & 177 & 253 & 130 & CRP \\
$887(851-1323)$ & 1230 & 1350 & 1630 & 823 & 1040 & 1660 & $\mathbf{4 2 1}$ & IgG \\
& $(913-1884)$ & $(605-1430)$ & $(913-1884)$ & $(605-1430)$ & $(913-1884)$ & $(913-1884)$ & $\mathbf{( 9 1 3 - 1 8 8 4 )}$ & $\mathrm{mg} / \mathrm{dl}$
\end{tabular}




\begin{tabular}{|c|c|c|c|c|c|c|c|c|}
\hline $8 / 13,7$ & $7 / 13$ & $\begin{array}{l}6 / \\
13,5\end{array}$ & $5 / 16$ & $\begin{array}{l}4 / \\
13,5\end{array}$ & $\begin{array}{l}3 / \\
17\end{array}$ & $\begin{array}{l}2 / \\
16\end{array}$ & $\begin{array}{l}1 / \\
16\end{array}$ & $\begin{array}{l}\text { Patient No } \\
\text { Age(year) }\end{array}$ \\
\hline $669(519-1226)$ & $\begin{array}{l}996 \\
(643-1071)\end{array}$ & $\begin{array}{l}1120 \\
(518-1226)\end{array}$ & $\begin{array}{l}1000 \\
(643-1071)\end{array}$ & $\begin{array}{l}571 \\
(518-1226)\end{array}$ & $\begin{array}{l}591 \\
(643-1071)\end{array}$ & $\begin{array}{l}1340 \\
(643-1071)\end{array}$ & $\begin{array}{l}257 \\
(643-1071)\end{array}$ & $\begin{array}{l}\mathrm{IgG}_{1} \\
\mathrm{mg} / \mathrm{dl}\end{array}$ \\
\hline $255(145-413)$ & $\begin{array}{l}291 \\
(179-435)\end{array}$ & $\begin{array}{l}431 \\
(145-413)\end{array}$ & $\begin{array}{l}493 \\
(179-435)\end{array}$ & $\begin{array}{l}281 \\
(145-413)\end{array}$ & $\begin{array}{l}236 \\
(179-435)\end{array}$ & $\begin{array}{l}439 \\
(179-435)\end{array}$ & $\begin{array}{l}183 \\
(179-435)\end{array}$ & $\begin{array}{l}\mathrm{IgG}_{2} \\
\mathrm{mg} / \mathrm{dl}\end{array}$ \\
\hline $27,3(24-136)$ & $\begin{array}{l}37 / \\
(17-83)\end{array}$ & $\begin{array}{l}33 \\
(24-136)\end{array}$ & $\begin{array}{l}36 \\
(17-83)\end{array}$ & $\begin{array}{l}62 \\
(24-136)\end{array}$ & $\begin{array}{l}25 \\
(17-83)\end{array}$ & $\begin{array}{l}68 \\
(17-83)\end{array}$ & $\begin{array}{l}20 \\
(17-83)\end{array}$ & $\begin{array}{l}\mathrm{IgG}_{3} \\
\mathrm{mg} / \mathrm{dl}\end{array}$ \\
\hline $21,9(6-96)$ & $\begin{array}{l}230 \\
(15-80)\end{array}$ & $\begin{array}{l}212 \\
(6-96)\end{array}$ & $\begin{array}{l}286 \\
(15-80)\end{array}$ & $\begin{array}{l}111 \\
(6-96)\end{array}$ & $\begin{array}{l}49 \\
(15-80)\end{array}$ & $\begin{array}{l}21 \\
(15-80)\end{array}$ & $\begin{array}{l}11 \\
(15-80)\end{array}$ & $\begin{array}{l}\mathrm{IgG}_{4} \\
\mathrm{mg} / \mathrm{dl}\end{array}$ \\
\hline $51(47-484)$ & $\begin{array}{l}820 \\
(88-322)\end{array}$ & $\begin{array}{l}97 \\
(83-282)\end{array}$ & $\begin{array}{l}206 \\
(88-322)\end{array}$ & $\begin{array}{l}93 \\
(83-282)\end{array}$ & $\begin{array}{l}64 \\
(88-322)\end{array}$ & $\begin{array}{l}200 \\
(88-322)\end{array}$ & $\begin{array}{l}184 \\
(88-322)\end{array}$ & $\begin{array}{l}\operatorname{IgM} \\
\mathrm{mg} / \mathrm{dl}\end{array}$ \\
\hline $88,3(67-433)$ & $\begin{array}{l}377 \\
(139-378)\end{array}$ & $\begin{array}{l}212 \\
(96-465)\end{array}$ & $\begin{array}{l}272 \\
(139-378)\end{array}$ & $\begin{array}{l}227 \\
(96-465)\end{array}$ & $\begin{array}{l}287 \\
(139-378)\end{array}$ & $\begin{array}{l}248 \\
(139-378)\end{array}$ & $\begin{array}{l}158 \\
(139-378)\end{array}$ & $\begin{array}{l}\operatorname{IgA} \\
\mathrm{mg} / \mathrm{dl}\end{array}$ \\
\hline 25,3 & 443 & 132 & 510 & 234 & 17 & 17 & 987 & $\mathrm{IgE} \mathrm{mg/dl}$ \\
\hline 44,8 & 45,3 & 57 & 599 & 50 & - & 37 & 25 & $\mathrm{CD}_{31}$ \\
\hline $76,3(58-82)$ & $\begin{array}{l}68 \\
(58-82)\end{array}$ & $\begin{array}{l}74 \\
(58-82)\end{array}$ & $\begin{array}{l}71 \\
(58-82)\end{array}$ & $\begin{array}{l}76,4 \\
(58-82)\end{array}$ & $\begin{array}{l}83 \\
(58-82)\end{array}$ & $\begin{array}{l}83,4 \\
(58-82)\end{array}$ & $\begin{array}{l}76 \\
(58-82)\end{array}$ & $\mathrm{CD}_{3}$ \\
\hline $43,9(27-57)$ & $\begin{array}{l}36 \\
(27-57)\end{array}$ & $\begin{array}{l}47 \\
(27-57)\end{array}$ & $\begin{array}{l}40 \\
(27-57)\end{array}$ & $\begin{array}{l}32,5 \\
(27-57)\end{array}$ & $\begin{array}{l}60 \\
(27-57)\end{array}$ & $\begin{array}{l}50 \\
(27-57)\end{array}$ & $\begin{array}{l}33 \\
(27-57)\end{array}$ & $\mathrm{CD}_{4}$ \\
\hline $36,9(19-38)$ & $\begin{array}{l}31 \\
(19-38)\end{array}$ & $\begin{array}{l}21 \\
(19-38)\end{array}$ & $\begin{array}{l}22 \\
(19-38)\end{array}$ & $\begin{array}{l}34,2 \\
(19-38)\end{array}$ & $\begin{array}{l}20 \\
(19-38)\end{array}$ & $\begin{array}{l}32,7 \\
(19-38)\end{array}$ & $\begin{array}{l}28 \\
(19-38)\end{array}$ & $\mathrm{CD}_{8}$ \\
\hline $14,1(10-30)$ & $\begin{array}{l}18 \\
(10-30)\end{array}$ & $\begin{array}{l}19 \\
(10-30)\end{array}$ & $\begin{array}{l}21 \\
(10-30)\end{array}$ & $\begin{array}{l}10,8 \\
(10-30)\end{array}$ & $\begin{array}{l}10 \\
(10-30)\end{array}$ & $\begin{array}{l}8,2 \\
(10-30)\end{array}$ & $\begin{array}{l}18 \\
(10-30)\end{array}$ & $\mathrm{CD}_{19}$ \\
\hline $8,8(8-30)$ & $\begin{array}{l}10 \\
(8-30)\end{array}$ & $\begin{array}{l}6 \\
(8-30)\end{array}$ & $\begin{array}{l}5 \\
(8-30)\end{array}$ & $\begin{array}{l}10,1 \\
(8-30)\end{array}$ & $\begin{array}{l}4,8 \\
(8-30)\end{array}$ & $\begin{array}{l}7,8 \\
(8-30)\end{array}$ & $\begin{array}{l}3 \\
(8-30)\end{array}$ & $\begin{array}{l}\text { CD } \\
16-56\end{array}$ \\
\hline 11,8 & 6,4 & 4,6 & 4,8 & 18 & - & 6,8 & 6,9 & $\mathrm{CD}_{27}$ \\
\hline
\end{tabular}

Table 3. Demographic data

\begin{tabular}{llllll}
\hline & & & total number of & $\begin{array}{l}\text { Number of } \\
\text { pediatric TB } \\
\text { cases (in Konya) }\end{array}$ & $\begin{array}{l}\text { Number of } \\
\text { pediatric TB } \\
\text { cases (in our } \\
\text { clinic) }\end{array}$ \\
\hline 2017 & $\begin{array}{l}\text { Population of } \\
\text { Konya (total) }\end{array}$ & $\begin{array}{l}\text { child population } \\
(0-19 \text { year })\end{array}$ & $\begin{array}{l}\text { TB cases (in } \\
\text { Konya) }\end{array}$ & 236 & 3 \\
2018 & 2.180 .149 & 724.720 & 236 & 21 & 4 \\
2019 & 2.205 .609 & 722.186 & 226 & 27 & 8 \\
2020 & 2.232 .374 & 719.363 & 235 & 33 & 19 \\
April/2021 & 2.250 .020 & 711.228 & 158 & 13 & 4 \\
\hline
\end{tabular}

Figüre 1 radiography and torax tomography 


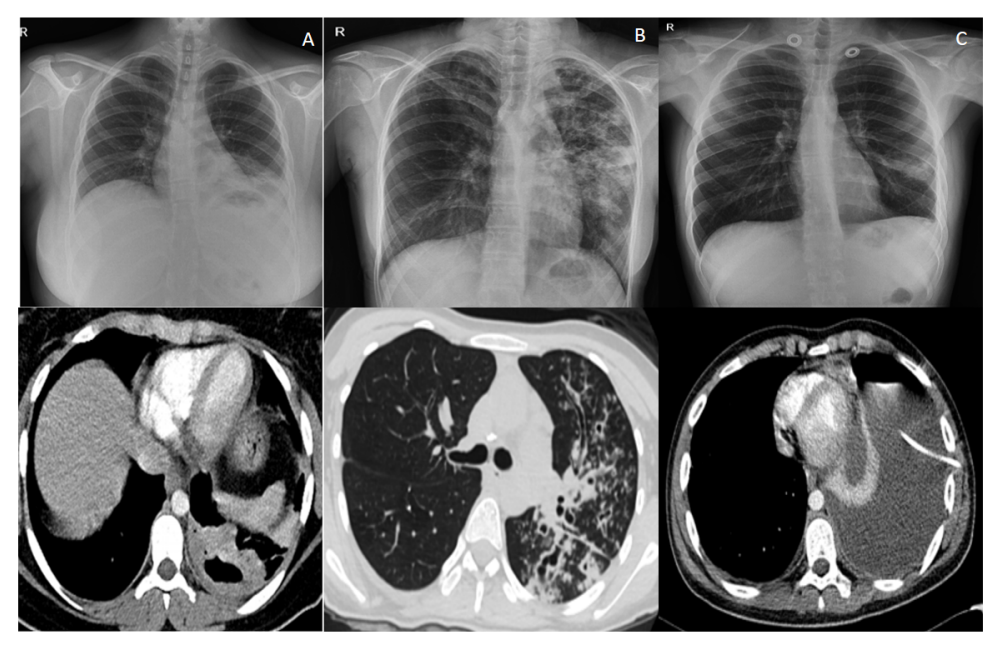

A: Mediastinal window on axial contrast-enhanced thoracic CT: Pneumonic consolidation with air bronchograms and cavitation in the left lower lobe and LAP in the left infrahilar region. Lung X-ray: Cavitation and left hilar LAP in consolidation located in the left lower lobe B: Non-contrast Thorax CT, axial parenchymal window, cavitation and bronchiectasis, fibroproductive lesions together, calcification, cavitation, consolidation and budding tree views. C: Contrast-enhanced axial CT, left massive tbc pleurisy and drain.

Figüre 2. Pathological results

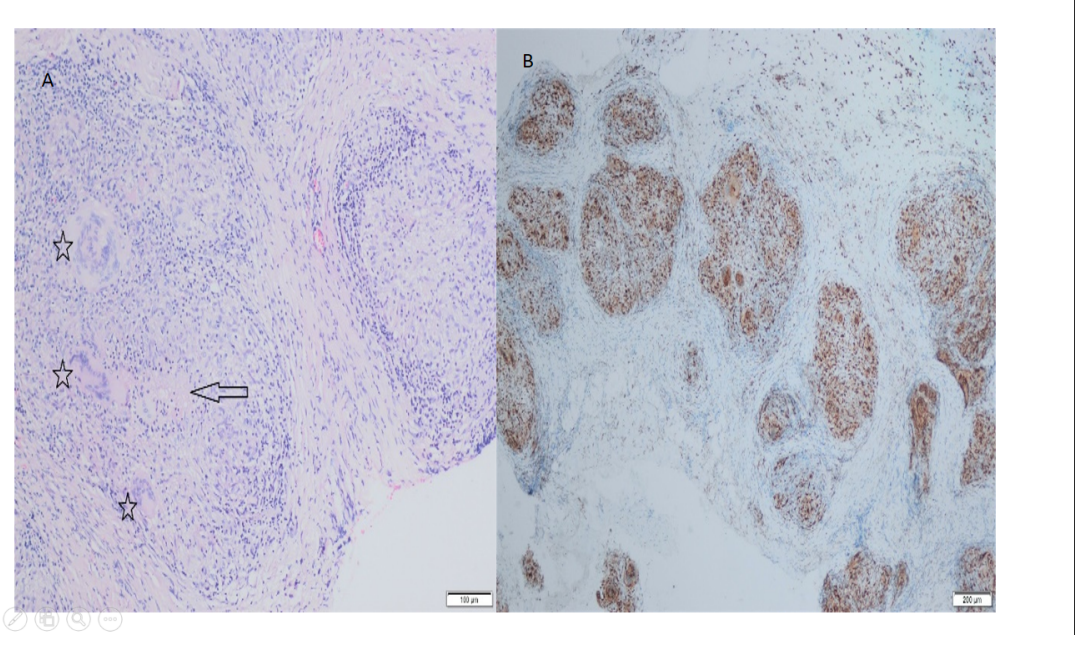

A: Granuloma formation consisting of multinuclear giant cells (stars), epithelioid histiocytes and lymphocytes with a small focus of necrosis (arrow) in the central part is seen (Hemotoxylin/Eosin, 100x). B: Immunohistochemical CD68 shows a positive reaction in histiocytes and giant cells forming granulomas (CD68, 40x).

\section{Funding}

There is no funding

\section{Conflicts of interest/Competing interests}


There is no conflict of interest

\section{Availability of data and material}

We saved our data in the excel system. The laboratory and imaging results of our patients are registered in the enlil database of our hospital. All of our patients diagnosed with tuberculosis were reported to the national database and their medications were given by the Ministry of Health.

\section{Code Availability}

Not applicable

\section{Authors' contributions}

Not applicable

\section{Ethics approval}

We obtained approval from the Ethics Committee of Necmettin Erbakan University with decision number $2012 / 3106$.

\section{Consent to participate}

There is approval for participation.

\section{Consent for publication}

There is consent for publication

\section{References}

1. Xu S, Chen M, Weng J. COVID-19 and Kawasaki disease in children. Pharmacol Res. 2020 Sep;159:104951

2. https://www.cdc.gov

3. Balasubramanian S, Rao NM, Goenka A, Roderick M, Ramanan AV. Coronavirus Disease 2019 (COVID-19) in Children - What We Know So Far and What We Do Not. Indian Pediatr. 2020 May 15;57(5):435-442.

4. Grasselli G, Greco M, Zanella A, Albano G, Antonelli M, Bellani G, et al. Risk Factors Associated With Mortality Among Patients With COVID-19 in Intensive Care Units in Lombardy, Italy. JAMA Intern Med. 2020 Oct 1;180(10):1345-1355.

5. Zhang Q, Bastard P, Liu Z, Le Pen J, Moncada-Velez M, Chen J, et al. Inborn errors of type I IFN immunity in patients with life-threatening COVID-19. Science. 2020 Oct 23;370(6515):eabd4570.

6. Béziat V, Tavernier SJ, Chen YH, Ma CS, Materna M, Laurence A, et al. Dominant-negative mutations in human IL6ST underlie hyper-IgE syndrome. J Exp Med. 2020 Jun 1;217(6):e20191804.

7. Suárez I, Fünger SM, Kröger S, Rademacher J, Fätkenheuer G, Rybniker J. The Diagnosis and Treatment of Tuberculosis. Dtsch Arztebl Int. 2019 Oct 25;116(43):729-735.

8. Metry AM, Al Salmi I, Al-Abri S, Al Ismaili F, Al Mahrouqi Y, Hola A, et al. Epidemiology and outcome of tuberculosis in immunocompromised patients. Saudi J Kidney Dis Transpl. 2017 Jul-Aug;28(4):806817.

9. Pekcan S., Aslan, A.T., Kiper, N., Doğru, D., Özçelik, U. Multicentric analysis of childhood tuberculosis in Turkey. Turkish Journal of Pediatrics, 2013, 55(2), pp. 121-129

10. Yang H, Lu S. COVID-19 and Tuberculosis. J Transl Int Med. 2020 Jun 25;8(2):59-65.

11. Liu W, Fontanet A, Zhang P, Zhan L, Xin Z, Tang F, et al. Pulmonary tuberculosis and SARS, China. Emerg Infect Dis 2006; 12:707-9.

12. Low JG, Lee CC, Leo YS, Low JG, Lee CC, Leo YS. Severe Acute Respiratory Syndrome and Pulmonary Tuberculosis. Clin Infect Dis 2004; 38: e123-5. 
13. Walaza S, Tempia S, Dawood H, Variava E, Moyes J, Cohen AL, et al. Influenza virus infection is associated with increased risk of death amongst patients hospitalized with confirmed pulmonary tuberculosis in South Africa, 2010-2011. BMC Infect Dis. (2015) 15:26.

14. Mendy J, Jarju S, Heslop R, Bojang AL, Kampmann B, Sutherland JS. Changes in Mycobacterium tuberculosis-Specific Immunity With Influenza co-infection at Time of TB Diagnosis. Front Immunol 2019; 9: 3093.

15. Noh JY, Lee J, Choi WS, Song JY, Seo YB, Kim IS, et al. Concurrent tuberculosis and influenza, South Korea. Emerg Infect Dis 2013; 19: 165-7. 55.

16. Tezcan İ, Berkel Aİ, Ersoy F, Sanal Ö. Sağllklı Türk çocukları ve erişkinlerde türbimetrik yöntemle bakılan serum immünglobülin düzeyleri. Çocuk Sağlığı ve Hastalıkları Dergisi 1996; 39: 649-656.

17. Scriba TJ, Coussens AK, Fletcher HA. Human Immunology of Tuberculosis. Microbiol Spectr. 2016 Oct; $4(5)$.

18. www.tuik.gov.tr

19. Turkey tuberculosis guide, 2018,2019 , republic of Turkey ministry of health,

20. Lamb GS, Starke JR. Tuberculosis in Infants and Children. Microbiol Spectr. 2017 Apr;5(2).

21. Jain VK, Iyengar KP, Samy DA, Vaishya R. Tuberculosis in the era of COVID-19 in India. Diabetes Metab Syndr. 2020 Sep-Oct;14(5):1439-1443.

22. Can Sarmoğlu R, Sili U, Eryuksel E, Olgun Yildizeli S, Cimsit C, Karahasan Yagci A. Tuberculosis and COVID-19: An overlapping situation during pandemic. J Infect Dev Ctries. 2020 Jul 31;14(7):721-725

23. Zahid A, Iqbal N, Moeen S, Irfan M. Post COVID-19 tuberculosis: An emerging threat of pandemic. Monaldi Arch Chest Dis. 2021 Mar 31.

24. Motta I, Centis R, D'Ambrosio L, García-García JM, Goletti D, Gualano G, et al. Tuberculosis, COVID-19 and migrants: Preliminary analysis of deaths occurring in 69 patients from two cohorts. Pulmonology. 2020 Jul-Aug;26(4):233-240.

25. Gupta N, Ish P, Gupta A, Malhotra N, Caminero JA, Singla R, et al. A profile of a retrospective cohort of 22 patients with COVID-19 and active/treated tuberculosis. Eur Respir J. 2020 Nov 19;56(5):2003408.

26. Stochino C, Villa S, Zucchi P, Parravicini P, Gori A, Raviglione MC. Clinical characteristics of COVID-19 and active tuberculosis co-infection in an Italian reference hospital. Eur Respir J. 2020 Jul 30;56(1):2001708.

27. Tadolini M, Codecasa LR, García-García JM, Blanc FX, Borisov S, Alffenaar JW, et al. Active tuberculosis, sequelae and COVID-19 co-infection: first cohort of 49 cases. Eur Respir J. 2020 Jul 9;56(1):2001398.

\section{Hosted file}

tables.docx available at https://authorea.com/users/448207/articles/547057-reactivation-oftuberculosis-and-covid-19 